\title{
HEALTH DISASTER MANAGEMENT GUIDELINES FOR EVALUATION AND RESEARCH IN THE UTSTEIN STYLE
}

\author{
भी भी भी० \\ VOLUME I. CONCEPTUAL FRAMEWORK OF DISASTERS \\ Task Force on Quality Control of Disaster Management<smiles>[Te]</smiles> \\ The World Association for Disaster and Emergency Medicine \\ do \\ The Nordic Society for Disaster Medicine \\ EDITORS \\ Knut Ole Sundnes, MD \\ Professor Marvin L. Birnbaum, MD, PhD
}

\section{COLLABORATING ORGANIZATIONS}

Mediterranean Council for Burns and Fire Disasters

Nordic International Rescue Foundation

Organization of African Unity

Swedish National Board on Health and Welfare

United Nations Department of Humanitarian Affairs

World Health Organization 
(C) 2003 Prehospital and Disaster Medicine

All rights reserved. No part of this publication may be reproduced or transmitted in any form or by any means, electronic or mechanical, including photocopy, recording or any information storage or retrieval system, without permission from the publisher

ISBN: 1049-023X

Editors: Knut Ole Sundnes, MD; Marvin L. Birnbaum, MD, PhD.; Elaine Daily Birnbaum, RN, BS, FCCM Designer: Kathie Campbell

Printed in USA 
This work was supported in part by grants from the Laerdal Foundation for Acute Medicine; the Royal Norwegian Ministry of Foreign Affairs, the Swedish National Board on Health and Welfare; the Swedish International Development Agency (SIDA);

Joint Medical Command Norwegian Defence Forces and the Nordic Council.

\section{Steering Committee}

Knut Ole Sundnes, MD, Norway, Chairman

Jacov Adler, MD, Israel

Professor Marvin L. Birnbaum, MD, PhD, USA

Professor Johan Calltorp, PhD, Sweden

Professor S. William A. Gunn, MD, Switzerland

Dr. Omar J. Khatib, MD, Organization of African Unity

Professor Michele Masellis, MD, Italy

Ernesto A. Pretto, MD, MPH, USA

Robert Souria, United Nations Department of Humanitarian Affairs, Switzerland Takashi Ukai, MD, Japan

\section{Jacov Adler \\ Richard Alderslade \\ Wahid Al Kharusi \\ Bishara Atiyeh \\ John Barrett \\ Marvin Birnbaum \\ Richard Bissell \\ Fredrick M. Burkle Jr. \\ José da Cruz \\ Albert K. Ekue \\ Jean Marie Fonrouge \\ S. William A. Gunn \\ Brian Gushalak \\ Jennifer Jaumotte \\ Omar J. Khatib}

Jacov Adler

Diego Buriot

Fredrick M. Burkle, Jr.

Elaine Daily-Birnbaum

Marvin Birnbaum

Judith M. Fisher

Jean Marie Fonrouge

Andre Griekspoor

Omar J. Khatib

\section{Gothenburg Congress Delegates}

$\begin{array}{cc}\text { Leo Klein } & \text { Kalwole Raheem } \\ \text { Mark A. Klyachko } & \text { Abdul Radjak } \\ \text { Joachim Kreysler } & \text { Edmund Ricci } \\ \text { Jeffrey Levitt } & \text { Leonid Roshal } \\ \text { Kristian Lexow } & \text { Margareta Rubin } \\ \text { Alessandro Loretti } & \text { Debarati Guha Sapir } \\ \text { Gudjón Magnússon } & \text { Knut Ole Sundnes } \\ \text { Michele Masellis } & \text { Elena Tivadze } \\ \text { Matti Matilla } & \text { Naruo Uehara } \\ \text { Eric Noji } & \text { Karl Axel Wallman } \\ \text { Karl-Axel Norberg } & \text { Harsh Wardhan } \\ \text { Idris Nur } & \text { Yukihiro Wato } \\ \text { Chief Segun Olusola } & \text { Jürgen Weyland } \\ \text { Pierre Perin } & \text { Klaus Wiersing } \\ \text { Jean Luc Poncelet } & \text { Dawit Zawde } \\ \text { Ernesto Pretto } & \end{array}$

Ernesto Pretto

Lyon Congress Delegates

Leo Klein

Mark A. Klyachko

Joachim Kreysler

Tore Laerdal

Jeffrey Levitt

Alassandro Loretti Matti Matilla

K. Joanne McGlown Marieu Portet
Claire Pirotte

Jean Luc Poncelet

Abiel Hamid Saïdi Edita Stok

Knut Ole Sundnes

Abdul Radjak

Leonid Roshal

Margareta Rubin

Elena Tivadze

\section{Correspondence}

KO Sundnes, MD, Department of Anaesthesia, 1306 Baerum P.T. Norway e-mail: knut.sundnes@sanr.mil.no

ML Birnbaum, MD, PhD, University of Wisconsin-Madison 3330 University Avenue, Madison, WI 53705 USA

e-mail: mlb@medicine.wisc.edu

Key Words: analysis; catastrophe; data collection; definitions; description of disaster; disaster; disaster management; disaster medicine; disaster phases; disaster research;

disaster responses; extrication; health consequences; health status; injuries;

interventions; measures of effectiveness; medical responses; morbidity; mortality; preparedness; needs assessment; public health; research; research design; research methods; risk evaluation; scope; template; type; Utstein style; warning 


\section{ACKNOWLEDGEMENT}

We express our profound gratitude to Elaine Daily-Birnbaum whose critical questions, editorial skills, and lingquistic abilities were significant in making this document what it has become.

We also are deeply in debt to Kathie Campbell who unselfishly devoted her time and professional skills to convert our manuscript into this book.

Without these two ladies, we still would have had a long way to go.

Knut Ole Sundnes

Marvin L. Birnbaum 


\section{FOREWORD}

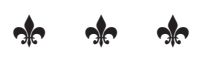

$\mathrm{D}$

URING THE PAST 20 years, natural disasters have killed at least 3 million people, and have affected 800 million more. Since 1990, 6 million have died as a direct result of armed conflicts around the world. Disasters don't only affect health directly through violence and trauma. The effect on the national social and economic infrastructure decreases access to education and damages the public health system.

Disaster preparedness and mitigation make a difference. Health systems and communities are better prepared to cope. Preparedness minimises excess morbidity and reduces damage when disasters happen. In complex emergencies, there are well-known and cost-effective public health measures that can save lives.

The basis for any successful public health intervention is sound health information. Research and evaluation provide health practitioners with the knowledge needed for preparedness and response. Standardised methods and definitions are necessary so that results of research and evaluation are valid and comparable. This book makes a valuable contribution to address this need.

Research and evaluation also provide good platforms to exchange knowledge. As humanitarian crises become more complex, with new and varied actors on the ground, strong partnerships and collaboration between organisations, experts, and disciplines is vital to build capacity.

It is for these reasons that the World Health Organization supports efforts to promote systematic approaches to evaluation and applied research in emergencies to strengthen the evidence base for disaster reduction from a public health perspective. This book provides important guidelines for those who are seeking methods for a better understanding of the impact of disasters on societies and people everywhere.

Dr. Gro Harlem Brundtland

Director-General

World Health Organization 
HEALTH DISASTER MANAGEMENT

Guidelines for Evaluation and Research in the Utstein Style 


\section{PREFACE}

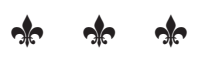

HIS IS THE FIRST OF four volumes to be published initially as
Supplements to Prehospital and Disaster Medicine and eventually as
a bound, free-standing, four volume set. These Guidelines and the Templates embedded within them are the result of more than seven years of discussions by members of the Steering Committee of the Task Force for Quality Control of Disaster Management and of two Congresses with participants from more than 40 countries. They are designed to provide the structure for the conduct of research and evaluations into disasters.

The current volume provides a discussion of a Conceptual Framework that forms the organization necessary for developing an understanding of the pathophysiology of disasters. Volume II contains a description of 14 basic societal functions that may be affected by an event producing a disaster. All of the basic societal functions are interactive and their respective functions are integrated by a Coordination and Control function. Volume III partitions the flow of disasters into Phases that are functional and not temporal. These Phases are linked together in a Disaster Response Template. Each of the Phases is described in detail and two severity scores (Disaster Severity Score and Health Disaster Severity Score) are introduced that will facilitate comparison of disasters caused by similar and dys-similar events. Volume IV provides a road map for the design and conduct of research or evaluations. It includes two additional templates that outline the steps in a research or evaluation project and the steps involved in the design of such projects.

The current Volume outlines the need for the structure encompassed in the Guidelines, and it seeks to establish a common nomenclature and a set of definitions essential for communication between the elements that comprise Disaster Medicine, as well as between Disaster Medicine and each of the other disciplines involved in Disaster Management. A comprehensive Glossary of Terms is included. Much of the confusion in discussions of disasters is related to the lack of a universally accepted set of definitions. Each discipline has its own set of definitions often for the same or similar terms. Disasters 
require interactions by many disciplines, some seemingly far distant from Disaster Medicine.

Chapters One and Two examine the human and economic scope of disasters. Together, they establish the need for structure in the performance and reporting of disaster research and for the evaluations of interventions for preparedness and for responses to events.

Chapter Three provides a set of definitions, some of which are new to the Science. Examples include the absorbing and buffering capacity of a given society to an event caused by the actualization of a specific hazard. The Chapter presents a logical framework into which each of terms fit. Using this structure, it seeks to clarify some of the terms whose definitions may differ between the many disciplines involved in disaster planning and response. Hopefully, use of this structured approach will help to clarify the confusion created by use of the same term in the many contexts in which it is applied.

Chapter Four identifies many of the factors that contribute to the probability that damage will occur from an event, given that an event is the actualization of a hazard. It uses a mathematically designed expression to relate hazards, risks, preparedness for, and responses to an event.

Chapter Five describes methods for defining the level of damage that results from an event, its impact on the functional status of the components of the affected society, and for identification of the needs that result from the damage. It uses the production process model and relates functions with requirements, consumption, and needs. Supplies are described in terms of available resources both human and material as goods and services. Societal functions and subfunctions have thresholds below which the supplies of goods and/or services are unable to provide all of their required functions. In addition, some functions, such as the available supply of potable water, also have a critical threshold below which the available level of supplies cannot support the lives of the affected population, manifest by a rise in the crude mortality rate. The need for appropriate indicators of function of levels of available supplies is developed.

Chapter Six examines analyses of interventions in terms of their effects, outcomes, benefits, and costs. It introduces a new concept, Best Outcome Without Intervention (BOWA) that may be helpful conceptually in determining the impact of an intervention or set of interventions.

Chapter Seven examines responses to an event highlighting the need for well-defined goals and objectives without which it is not possible to define 
the effectiveness of the response. Further, it examines the relationships between indicators, their thresholds, and the development of standards. Recovery is defined as is management as the process taken to minimize the damage and restore the pre-event status of the society impacted by an event.

Lastly, in this Volume, some of the ethical dilemmas associated with disasters and their relations to international law are discussed. The issues raised are meant to provoke discussion and are not proposed as definitive solutions to all of the dilemmas associated with disasters and their management.

All together, the Conceptual Framework should stimulate the development of a common language that will promote the understanding of the pathophysiology of disasters. To this end, a Glossary of Terms also is provided that expands on the work pioneered by SWA Gunn in the first attempt to gain understanding through standardization of the language and concepts we use in describing the events that comprise the greatest threats to humankind. It is not intended to be the definitive and final work, but should remain a dynamic document. It should form the basis for reporting of all future research and evaluations into all aspects of disaster medicine. Without using such a structure, it will be difficult to relegate hazards to a state that they no longer pose a massive threat to us and our children. We look forwards to your responses and input.

Knut Ole Sundnes, MD

Professor Marv Birnbaum, MD, PhD 


\section{TABLE OF CONTENTS

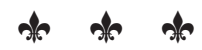

Foreword

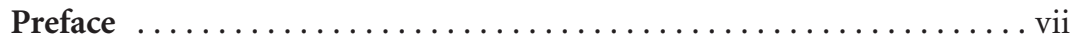

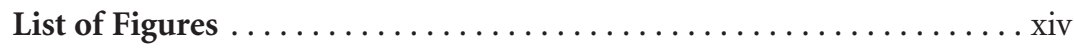

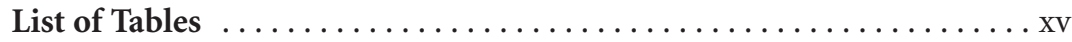

Acronyms and Abbriviations $\ldots \ldots \ldots \ldots \ldots \ldots \ldots \ldots \ldots \ldots \ldots \ldots . \ldots \ldots$

VOLUME I

I. Introduction

Chapter One Introduction $\ldots \ldots \ldots \ldots \ldots \ldots \ldots \ldots \ldots \ldots \ldots \ldots$

Chapter Two Current Methods Used for Evaluation and Research . . . 25

II. Conceptual Framework

Chapter Three Overview and Concepts ..................... 31

Chapter Four Conceptual Model ....................... 56

Chapter Five Functional Status, Thresholds, Indicators, Damage,

Requirements, Supplies, and Needs . ..................69 69

Chapter Six Interventions, Outcomes, Benefits, and Costs ........ 103

Chapter Seven Responses, Relief, and Recovery .............. 113

Chapter Eight Ethical Issues . ........................ 128

(The following sections will be published in future issues)

\section{VOLUME II}

\section{Basic Functional Components of a Society}

Overview of Basic Societal Functions

Description of the Basic Societal Functions

Public Health

Medical Care

Water and Sanitation

Shelter and Clothing

Food

Energy Supplies

Search and Rescue

Public Works and Engineering

The Environment

Logistics and Transport

Security

Communications

Economy

Education

Co-ordination and Control 


\section{VOLUME III}

\section{Research and the Templates}

Current Methods Used for Evaluations and Research

Overview of the Disaster Evaluation-Research Templates

\section{The Disaster Response Template}

Overview of the Disaster Response Template

Phase 1. Pre-Event Status of the Population Affected

Phase 2. The Event

Phase 3. Damage

Phase 4. Health Disaster

Phase 5. Needs Assessments

Phase 6. Responses

Phase 7. Changes in Health Status

Phase 8. Restored Health Status

\section{VOLUME IV}

VI. Guidelines and Template for the Conduct of Evaluation-Research

Introduction to Evaluation Research

Introduction to the Template for Evaluation-Research

Designing Evaluation Research

Disaster Evaluation-Research Template

\section{Summary, Conclusions, and Recommendations}

Summary and Conclusions

Recommendations

Glossary of Terms .............................. 144

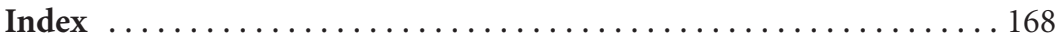




\section{LIST OF FIGURES}

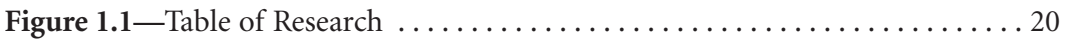

Figure 3.1-Diagrammatic representation of definitions .............. 35

Figure 3.2-Graphical representation of the time course of sudden-, gradual-,

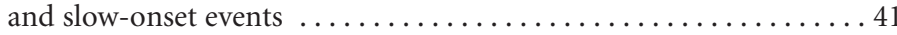

Figure 3.3-Flow chart illustrating some of the pathways for damage related to

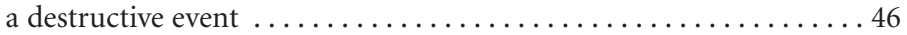

Figure 3.4-Relationship between vulnerability and resilience .......... 49

Figure 3.5-Relationship between damage and the absorbing capacity of the

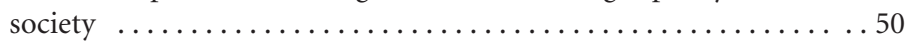

Figure 3.6 - Buffering capacity of a function in two different societies . . . . . . 52

Figure 4.1-Relationship between productive disaster response and total vulnerability . . . . . . . . . . . . . . . . . . . 64

Figure 4.2-Schematic depicting the probability damage $\left(\mathrm{P}_{\mathrm{D}}\right)$ as a function of

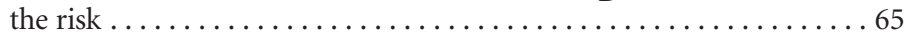

Figure $5.1-$ A production process $\ldots \ldots \ldots \ldots \ldots \ldots \ldots \ldots \ldots \ldots \ldots \ldots \ldots \ldots \ldots$

Figure $5.2-$ Complex production processes $\ldots \ldots \ldots \ldots \ldots \ldots \ldots \ldots \ldots \ldots \ldots \ldots \ldots \ldots$

Figure 5.3-Relationships between consumption and supply ......... 73

Figure 5.4-Supply inadequate to maintain the functional or pre-event state . . . . 74

Figure 5.5-Relationship between damage needs of five segments of the affected

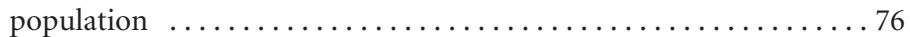

Figure 5.6-Threshold as an all-or-none relationship $\ldots \ldots \ldots \ldots \ldots \ldots 78$

Figure 5.7-Possible relationships between the level of available supplies and

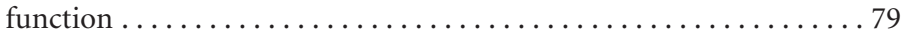

Figure 5.8-Relationship between level of water supply and function . . . . . 81

Figure 5.9-Conceptual method for identifying thresholds . . . . . . . . . 83

Figure 5.10-Schematic depicting cause-effect relationships of one resource

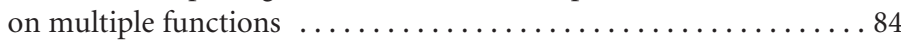

Figure 5.11-Hypothetical model illustrating relationship between function and critical threshold of supply ..................... 88

Figure 5.12—Plot of supplies vs functional and critical thresholds on consecutive ... assessments ...................................... 90

Figure 5.13 - Plot of supplies on Days 1, 4, 10, and 30 following a sudden onset

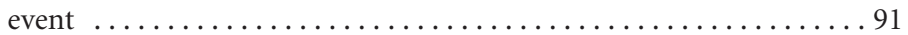

Figure 5.14-Theoretical model depicting the impact of two events of different magnitudes on a given society $\ldots \ldots \ldots \ldots \ldots \ldots \ldots \ldots \ldots$ 
Figure 5.15-Severity scores vs survival for patients with ischaemic heart disease

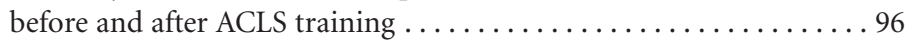

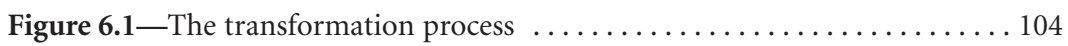

Figure 6.2-The transformation process as related to disasters . . . . . . . . 107

Figure 6.3-The effects of a recovery from an acute event in two societies . . . 108

Figure 6.4-Diagrammatic representation of cost-efficiency, cost-effectiveness, and cost-benefit $\ldots \ldots \ldots \ldots \ldots \ldots \ldots \ldots \ldots \ldots \ldots$

Figure 7.1—Example of different indicators for food supply or nutritional status

\section{LIST OF TABLES}

Table 1.1-Numbers of natural disasters, persons affected and killed for all natural disasters from $1951-2000 \ldots \ldots \ldots \ldots \ldots \ldots \ldots \ldots \ldots \ldots$

Table 1.2-Numbers of persons affected and killed by natural disasters from

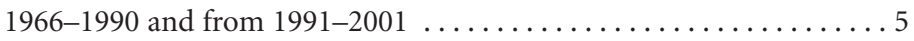

Table 1.3-Numbers of technological disasters, persons affected and killed for all technological disasters from $1951-2000 \ldots \ldots \ldots \ldots \ldots \ldots \ldots \ldots$

Table 1.4-Available economic costs for all natural disasters from 1951-2000 . . 10

Table 1.5-Available economic costs for all technological disasters from

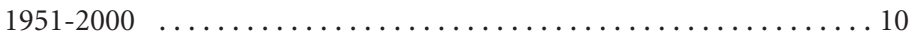

Table 1.6 - Number of disasters and reported costs of disasters from 1966-1990

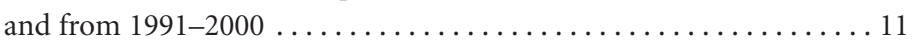

Table 3.1-Classification of known hazards ..................... 36

Table 3.2-Relationships between a precipitating event (absence of rain) and outcome (crude mortality rate) $\ldots \ldots \ldots \ldots \ldots \ldots \ldots \ldots \ldots \ldots \ldots \ldots \ldots \ldots$

Table 3.3-Differences in the definitions between types of onset and the

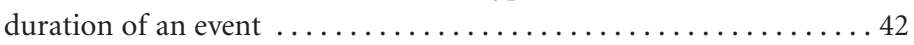




\section{ACRONYMS AND ABBRIVIATIONS}

$\begin{array}{ll}\text { BATNA } & \text { Best Alternative to Negotiated Agreement } \\ \text { BOWA } & \text { Best Alternative To Negotiated agreement } \\ \text { CRED } & \text { Center for Research on Epidemiology on Disaster } \\ \text { CRID } & \text { Regional Disaster Information Center } \\ \text { CSP } & \text { Center for Systemic Peace } \\ \text { DCCP } & \text { Disaster Critical Control Point } \\ \text { DHA } & \text { Department of Humanitarian Affairs } \\ \text { DMTP } & \text { Disaster Management Training program } \\ \text { FCDP } & \text { Force Commander's Policy Directive } \\ \text { HR } & \text { United Nations Declaration of Human Rights } \\ \text { ICIHI } & \text { Independent Commission on International Humanitarian Issues } \\ \text { ICRC } & \text { International Committee of Red Cross } \\ \text { IDNDR } & \text { International Decade for Natural Disaster Reduction } \\ \text { IDP } & \text { Internally Displaced People } \\ \text { IGO } & \text { Inter-Governmental Organization } \\ \text { IHL } & \text { International Humanitarian Law } \\ \text { IOMC } & \text { Inter-Organization Program for the Sound Management of Chemicals } \\ \text { IPCC } & \text { Intergovernmental Panel on Climate Change } \\ \text { ISDR } & \text { International strategy for Disaster Reduction } \\ \text { NATO } & \text { North Atlantic Treaty Organization } \\ \text { NCDC } & \text { National Climatic Data Center } \\ \text { NGO } & \text { Non-Governmental Organization } \\ \text { OAU } & \text { Organization of African Unity } \\ \text { OCHA } & \text { (UN) Office for Coordination of Humanitarian Affairs } \\ \text { OFDA } & \text { Office of Foreign Disaster Assistance } \\ \text { PAHO } & \text { Pan-American Health Organization } \\ \text { PDM } & \text { Prehospital and Disaster Medicine } \\ \text { RoE } & \text { Rules of Engagement } \\ \text { SIPRI } & \text { Stockholm International Peace Research Institute } \\ \text { SOP } & \text { Standard Operational Procedure } \\ \text { UDPC } & \text { Uppsala University Department for Peace and Conflict Research } \\ \text { UATI } & \text { International Union of ytechnical Associations and Organizations } \\ \text { UK } & \text { United Kingdom } \\ \text { UNDRO } & \text { United Nations Disaster Relief Coordinating Office } \\ \text { UNFCCC } & \text { United Nations Framework Con vention on Climate Change } \\ \text { UNOG } & \text { United Nations Office in Geneva } \\ \text { US } & \text { United States (of America) } \\ \text { WADEM } & \text { World Association for Disaster and Emergency Medicine } \\ \text { WFEO } & \text { World Federation of Engineering Organization } \\ \text { WHO } & \text { World Health Organization } \\ \text { WMA } & \text { World Medical Association } \\ & \end{array}$

